\title{
Community Structure of Soil Nematodes Associated with Solanum Tuberosum
}

\author{
Martin M. Matute ${ }^{1}$, Yvonne A. Manning ${ }^{1} \&$ Mariam I. Kaleem ${ }^{1}$ \\ ${ }^{1}$ Department of Biology, University of Arkansas, 1200 North University Drive,Pine Bluff, Arkansas, USA \\ Correspondence: Martin M. Matute, Department of Biology, University of Arkansas, 1200 North University Drive, \\ Pine Bluff, Arkansas, USA. E-mail: matutem@uapb.edu
}

$\begin{aligned} & \text { Received: September 24, } 2012 \quad \text { Accepted: October 25, } 2012 \quad \text { Online Published: December 13, } 2012 \\ & \text { doi:10.5539/jas.v5n1p44 }\end{aligned} \quad$ URL: http://dx.doi.org/10.5539/jas.v5n1p44

\begin{abstract}
The soil nematode food web structure under a potato crop compared to a forest control treatment was investigated for 10 months. All nematode functional guilds were recovered from both treatments. Higher populations of enrichment nematodes (bacterivores and fungivores) were recovered in the potato plots and this is attributed to possible higher amounts of organic matter in the crop plots as compared to the forest control. For the pest suppression species, higher populations of carnivorous nematodes were recorded in the forest samples, while higher populations of the omnivorous nematodes were recorded in the potato plots. It will therefore seem that while the environmental response of predatory (carnivorous) nematodes is linked to physical perturbation, food sources are a more important factor in the environmental response of the omnivorous nematodes. Whereas the plant-feeding species of the $\mathrm{Pl}_{3}$ class were significantly higher in the crop plots, the $\mathrm{Pl}_{5}$ plant species were significantly higher in the forest control samples. These differences are attributed to host specificity. Overall, the plant-feeding nematodes dominated ( 9 families, 14 genera, $35.73 \%$ total biomass contribution), followed by the enrichment nematodes ( 8 families, 12 genera, 33.53\% total biomass), and then the pest suppression species ( 9 families, 19 genera, $30.76 \%$ total biomass). Based on these results plant-parasitic nematodes of the $\mathrm{Pl}_{3} \mathrm{cp}$ class particularly Helicotylenchus mucronatus, Rotylenchus buxophilus, and Meloidogyne microcephala, are considered a potential threat to potato production in the study area.
\end{abstract}

Keywords: soil food web, nematodes, potato, forest

\section{Introduction}

\subsection{Background}

Solanum tuberosum or potato is a high energy staple crop. It contains carbohydrates, dietary fiber, sugars, and proteins; Calcium and Iron; Vitamin C and trace elements of thiamin, riboflavin, folate, magnesium, phosphorus, and zinc (Washington State Potato Commission 2012). Despite their importance, the potato industry worldwide loses up to $12.2 \%$ of annual potato production due to the destructive activities of plant parasitic nematodes. This loss is estimated in monetary terms to over $\$ 5.7$ billion annually (Sasser, 1989).

Worldwide, the plant parasitic nematode genera associated with potato are Globodera, Meloidogyne, Pratylenchus, Trichodorus, Paratrichodorus, Ditylenchus, and Nacobbus (Sasser, 1989). The study by Hafez et al. (1992) in Idaho and Eastern Oregon documented a total of nine parasitic nematode genera of potato, viz; Aphelenchoides, Coslenchus, Ditylenchus, Geocenamus, Criconemella, Helicotylenchus, Pratylenchus, Trichodorus and Trophonema.

It is thought that the pathogenic and destructive ability of plant-parasitic nematodes is associated with the soil food web structure of nematodes and other microorganisms in the soil. Trophically soil nematodes are of the following categories; bacterial feeders, fungal feeders, carnivores or predators, omnivores, and plant root feeders or herbivores. Bacterivores and fungivores increase soil fertility, carnivores and omnivores control or suppress pest species, and plant-parasitic nematodes are root destructive (Matute et al., 2009; Ferris \& Matute, 2003; Ferris et al., 2001; Bongers \& Ferris, 1999; Yeates, 2003). Functional guilds of soil nematodes are characterized by trophic group and by life history characteristics expressed along a colonizer-persister (c-p) scale (T. Bongers \& M. Bongers, 1998; Ferris et al., 2001). 
For the most part, studies on the nematodes of crop plants are restricted to the plant-parasitic nematodes, which reveal only a partial picture of the soil nematode community structure. The presence of plant-parasitic nematodes may not necessary be detrimental to the health of the crop. The interpretation need be in relation to the composition and abundance of other soil nematode guilds and the biomass they respectively contribute, viewing the food web holistically (Matute et al., 2003).

\subsection{Objectives}

The main aim of this investigation was to document for the first time the soil nematodes associated with potato in Central Arkansas and to determine if they are a potential constraint to potato production in the study area. This was to be achieved by studying the whole nematode food web structure, comparing it with nematodes from a pristine adjacent wooded forest, and converting nematode counts to nematode biomass to enable comparisons across nematode functional guilds.

\section{Materials and Methods}

\subsection{Study Sites}

The site for this study was Marche in Pulaski County, Central Arkansas. There were two main treatments. A wooded forest consisting of a combination of cedars, figs, pines (mostly), etc. The potato farm was carved out of the wooded forest some 30 years ago. While the forest has remained undisturbed, the potato plot has been farmed every year since 30 years back. The piece of farmed land adjacent to the forest was divided into plots and each plot has over the years been grown to different crops in rotation e.g corn, beans, cabbages, carrots, peppers, potato, etc. The plot studied was a monoculture of potato of approximately $18 \times 12.8 \mathrm{~m}\left(230.4 \mathrm{~m}^{2}\right)$ and was grown continuously with potato for the last two growing seasons. Before the potato crop, the plot was planted with corn plants. The soils in the study area are described as flat alluvial soils of the Delta and a pH range of 4.0 to 7.5 (Ferguson, 1920). In March, the land was tilled and limed and then covered with dry Bermuda grass (collected from mowed lawns). In April, the beds were made and the crops planted. Crops were grown on ridges or beds that were approximately $12.8 \mathrm{~m}$ long, $1.25 \mathrm{~m}$ wide and $45 \mathrm{~cm}$ high. The beds were laid horizontal to the plot and approximately $0.5 \mathrm{~m}$ apart. A total of 10 beds were contained in the potato plot and four were randomly chosen for sampling. An approximate area to the potato plot was demarcated in the forest and four random sites selected for sampling. Thus there was the pristine forest as the control treatment and potato plot as the disturbed treatment.

\subsection{Sample Collection}

Eight to 10 subsamples were collected from the mid-portion of the bed (microsite) along its entire length. The soil samples were collected using a foot-driven tube soil sampler, with a diameter of $2.8 \mathrm{~cm}$, at an approximate depth of $15 \mathrm{~cm}$. The subsamples constituted one composite sample for each replicate or microsite. Samples were collected every four weeks, for 10 months, December through September. Samples were therefore collected during periods of crop growth, winter, and preparation for planting. Samples were similarly collected from the forest microsites during each sampling period. Soil samples were placed in an insulated box for transportation to the laboratory. Samples that were not analyzed immediately were kept in cold storage.

\subsection{Nematode Recovery}

In the laboratory, each composite soil sample from a microsite was mixed and $100 \mathrm{~mL}$ used to extract nematodes. Nematodes were recovered using a combination of sieving, decanting and Baermann funnels (Barker, 1985). A $100 \mathrm{~mL}$ subsample was transferred unto a container with $10 \mathrm{~L}$ of water. Clumps of the samples were dissolved manually. This mixture was homogenized, passed through a 60 um and then through a 400 um mesh sieve. Each process was decanted. The retained sample by the $400 \mathrm{um}$ mesh sieve was then transferred onto a Baermann funnel assemblage and incubated for 72 hours. After the incubation period, $15 \mathrm{~mL}$ of each sample was tapped and subjected to qualitative and quantitative analysis (Ferris \& Matute, 2003).

\subsection{Nematode Quantification and Identification}

All nematodes in a sample were counted under a dissecting microscope. The sample was then centrifuged and the supernatant removed. The pellet was then resuspended in about $0.25 \mathrm{~mL}$ water and spread on a microscope slide, covered with a cover slip, and sealed with fingernail polish. A minimum of 100 nematodes on each slide was identified to genus (and sometimes species) level. The actual abundance of each taxon was adjusted according to the total number of nematodes in the sample (Ferris \& Matute, 2003).

\subsection{Data Analysis}

Three types of analyses were carried out depending on the parameter being sorted. 


\subsubsection{Unpaired t-test (Townsend, 2002)}

This test statistic was used to compare nematode colonizer-persister (cp) classes of the different nematode functional guilds between the forest samples and potato plot samples. The aim was to elucidate if and how nematode populations have changed in both treatments after some many years.

\subsubsection{Single Classification Analysis of Variance (Sokal \& Rohlf, 1973)}

This statistic was used to determine if there was a statistically significant difference in the populations of $\mathrm{cp} 3 / \mathrm{Pl}_{3}$ nematodes in the potato plot and if the populations of these nematodes significantly differed on a monthly basis.

\subsubsection{Biomass Units Calculation from a Colonizer-persister (cp) Perspective (Matute et al., 2009)}

Matute et al. (2009) suggested that nematodes be assigned biomass units based on their cp values e.g cp1=1 biomass unit, $\mathrm{cp} 3=3$ biomass units, $\mathrm{cp} 5=5$ biomass units $(b u)$, etc. While this does not in any way reflect actual biomass units for the nematodes, it is directly related to the sizes of the nematodes. While actual biomass values are known for certain nematodes, this is not true for all nematodes. Therefore to uniformize any calculations or analysis involving a wide array of nematodes of known and unknown actual biomass units, a common format or method be used for any meaningful comparison. By the Matute et al method, the biomass of for example $20 \mathrm{cp} 4$ nematodes will be $20 \times 4=80$ biomass units (or $b u$ ), likewise the biomass for $346 \mathrm{cp} 1$ nematodes will be $346 \times 1=346$ bu, etc. While this suggested method does not give actual biomass values, it does give an idea as to how much biomass is contributed by each cp class of nematodes in an ecosystem. There are five ecological functional groups of soil nematodes-bacterivores, fungivores, herbivores or plant feeders, carnivores and omnivores. Of these, an abundance of the plant feeders signify and unhealthy soil, while an abundance of the bacterivores and fungivores will signify fertile soils, etc. A comparison of the biomass associated with each functional group, should reveal whether plant-parasitic nematodes be considered a potential threat to potato production in the study site or not just yet.

\section{Results}

\subsection{Control Versus Potato Plots}

\subsubsection{Bacterivorous Nematodes}

A total of six families and 10 genera of bacterial feeding nematodes were recovered (Table 1). The nematodes recovered were of the $\mathrm{cp} 1\left(\mathrm{Ba}_{1}\right), \mathrm{cp} 2\left(\mathrm{Ba}_{2}\right)$, and $\mathrm{cp} 3\left(\mathrm{Ba}_{3}\right)$ classes respectively. The mean number per $100 \mathrm{~mL}$ sample of $\mathrm{Ba}_{1}$ nematodes for the forest control was 47.9 as compared to the 84.1 nematodes for the potato plots. This difference in mean number of nematode count was statistically not significant $(\mathrm{P}<0.05)$ between the control and potato plots. However these values represent a $75.57 \%$ increase in $\mathrm{Ba}_{1}$ nematode populations in potato plots as compared to the control. The same trend was observed for the $\mathrm{Ba}_{2}$ nematodes as was for the $\mathrm{Ba}_{1}$ nematodes, i.e there was no significant difference in the populations of the $\mathrm{Ba}_{2}$ nematodes for both treatments( forest $110.6 \mathrm{vs}$ 114.6 potato), though the population in the potato plots was higher by $3.6 \%$. However, for the $\mathrm{Ba}_{3}$ nematodes, there was a significant difference $(\mathrm{P}<0.05)$ between the populations of both treatments. The potato plots recorded a mean of 34.6 nematodes as compared to the 6.1 nematodes of the forest control. This represented an increase factor of $467.21 \%$ in the potato plots.

\subsection{Fungivorous Nematodes}

Two families and two genera of fungivorous nematodes were recovered (Table 1). The fungal feeding nematodes recovered were all of the $\mathrm{cp} 2\left(\mathrm{Fu}_{2}\right)$ group. There was no significant difference between the populations of the control and potato plots, though a slight increase of $0.007 \%$ was observed for the potato plots.

\subsubsection{Carnivorous or Predatory Nematodes}

A total of six families and 10 genera of predatory nematodes were recorded (Table 2). The recovered carnivorous (or predatory) nematodes were of the cp3 $\left(\mathrm{Ca}_{3}\right)$, cp4 $\left(\mathrm{Ca}_{4}\right)$, and cp5 $\left(\mathrm{Ca}_{5}\right)$ groups respectively. There was no significant difference in the populations of these nematodes between the forest control and potato plots. However, there was a decrease in population of these nematodes in the potato plots, for example $\mathrm{Ca}_{3}-56.8 \%$ decrease, $\mathrm{Ca}_{4}-16.33 \%$ decrease, and $\mathrm{Ca}_{5}-25.85 \%$ decrease. 
Table 1. Bacterivorous and fungivorous nematodes associated with potato and control plots

\begin{tabular}{|c|c|c|c|c|c|c|c|c|c|c|c|}
\hline Cp class /Family & Genus & Dec & Jan & Feb & Mar & Apr & May & Jun & Jul & Aug & Sep \\
\hline $\mathrm{Ba}_{1}$ & Mesorhabditis & 246 & - & 20 & 6 & 3 & 9 & 5 & 3 & - & 11 \\
\hline \multicolumn{12}{|l|}{ Rhabditidae } \\
\hline & & 42 & 89 & 55 & 76 & 16 & 82 & 62 & 35 & 29 & - \\
\hline & Rhabditis & - & - & - & 27 & - & - & 10 & - & 9 & 21 \\
\hline & & - & - & - & - & - & - & - & - & - & 15 \\
\hline & Cruznema & - & - & - & - & - & - & - & 4 & - & - \\
\hline & & - & - & - & - & - & - & - & - & - & - \\
\hline $\mathrm{Ba}_{1}$ & Panagro- & - & - & 5 & 6 & 3 & 5 & - & 24 & 31 & 11 \\
\hline
\end{tabular}

Panagrolai- laimus

midae

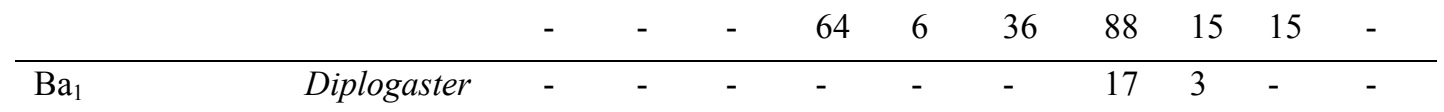

Diplogasteridae

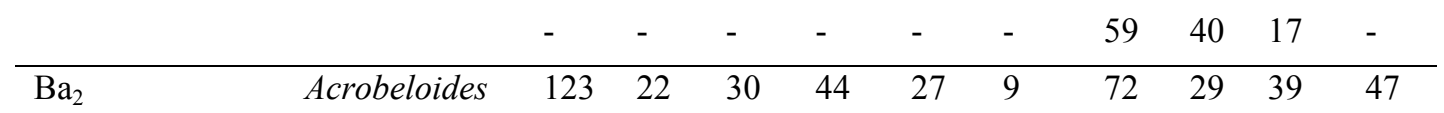

Cephalobidae

\begin{tabular}{|c|c|c|c|c|c|c|c|c|c|c|c|}
\hline & & 18 & - & 96 & 6 & - & 30 & 57 & 29 & 11 & 37 \\
\hline & \multirow[t]{2}{*}{ Cephalobus } & 105 & 37 & 5 & 44 & 42 & 5 & 57 & 6 & 27 & 6 \\
\hline & & 26 & 30 & 26 & - & 32 & 72 & 6 & 8 & - & - \\
\hline & \multirow[t]{2}{*}{ Acrobeles } & - & 15 & - & - & - & - & - & - & - & 6 \\
\hline & & - & - & - & - & - & - & - & - & - & 3 \\
\hline \multirow{3}{*}{$\begin{array}{l}\mathrm{Ba}_{2} \\
\text { Plectidae }\end{array}$} & Plectus & 168 & 44 & 3 & 25 & 13 & 14 & 21 & 10 & 5 & 6 \\
\hline & & & & & & & & & & & \\
\hline & & 67 & 204 & 110 & 143 & 43 & 22 & 9 & 15 & 3 & 43 \\
\hline \multirow{3}{*}{$\begin{array}{l}\mathrm{Ba}_{3} \\
\text { Prismatolai- } \\
\text { midae }\end{array}$} & Prismato- & - & - & - & - & - & - & 37 & 3 & - & 21 \\
\hline & laimus & & & & & & & & & & \\
\hline & & 9 & 122 & 24 & 6 & 14 & - & 74 & 15 & 39 & 43 \\
\hline \multirow{3}{*}{$\begin{array}{l}\mathrm{Fu}_{2} \\
\text { Aphelenchoi- } \\
\text { didae }\end{array}$} & Aphelen- & 81 & 88 & 35 & 76 & 3 & 9 & 11 & 21 & 65 & 37 \\
\hline & choides & & & & & & & & & & \\
\hline & & 54 & 61 & 95 & 17 & 18 & 37 & 25 & 36 & 6 & 9 \\
\hline $\mathrm{Fu}_{2}$ & Aphelenchus & - & - & - & 19 & - & 5 & 5 & 5 & - & - \\
\hline Aphelenchidae & & 27 & 38 & 12 & - & - & 14 & - & 3 & 2 & 3 \\
\hline
\end{tabular}

First row values are for the forest control and second row values are for the potato plots; $\mathrm{Ba}=$ Bacterial feeding nematodes; $\mathrm{Fu}=$ Fungal feeding nematodes; Values are per $100 \mathrm{~mL}$ soil sample. 
Table 2. Carnivorous and Omnivorous nematodes associated with potato and control plots

\begin{tabular}{|c|c|c|c|c|c|c|c|c|c|c|c|}
\hline $\begin{array}{l}\text { Cp class/ } \\
\text { Family }\end{array}$ & Genus & Dec & Jan & Feb & Mar & Apr & May & Jun & Jul & Aug & Sep \\
\hline \multirow{2}{*}{$\begin{array}{l}\text { Ca3 } \\
\text { Tripylidae }\end{array}$} & Tripyla & - & - & - & - & 9 & - & 16 & 3 & - & 16 \\
\hline & & - & - & - & - & - & - & - & - & 2 & 17 \\
\hline \multirow{10}{*}{$\begin{array}{l}\text { Ca4 } \\
\text { Mononchidae }\end{array}$} & Mylonchulus & 30 & 8 & - & - & - & - & - & - & - & 22 \\
\hline & & 3 & - & - & 16 & - & - & - & - & - & 58 \\
\hline & Clarkus & - & - & - & - & 16 & - & - & 6 & - & - \\
\hline & & - & - & - & - & 2 & - & - & - & - & - \\
\hline & Mononchus & - & - & - & - & 8 & - & - & - & - & - \\
\hline & & - & - & - & - & - & - & - & - & - & - \\
\hline & Miconchus & - & - & - & - & - & - & - & - & - & - \\
\hline & & - & - & - & - & - & - & - & 3 & - & - \\
\hline & Prionchulus & - & - & - & - & - & - & - & - & - & 6 \\
\hline & & - & - & - & - & 3 & 16 & - & - & - & - \\
\hline \multirow{2}{*}{$\begin{array}{l}\text { Ca5 } \\
\text { Nygolaimidae }\end{array}$} & Nygolaimus & - & - & - & - & - & - & - & - & - & 110 \\
\hline & & - & - & - & - & - & - & - & - & - & 3 \\
\hline $\begin{array}{l}\text { Ca5 } \\
\text { Nygolai- } \\
\text { mellidae }\end{array}$ & Nygolaimellus & - & - & - & - & - & - & 16 & 12 & 9 & - \\
\hline
\end{tabular}

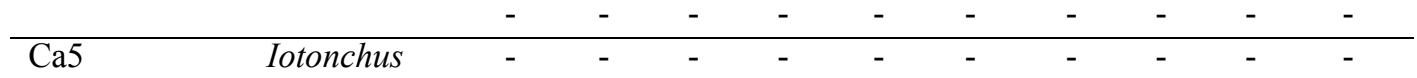

Iotonchiidae

\begin{tabular}{llllllllllll} 
& 5 & - & - & - & - & - & 6 & 3 & - & - \\
\hline $\mathrm{Ca5}$ & Discolaimus & - & - & - & - & - & - & - & - & - & -
\end{tabular}

Discolaimidae

\begin{tabular}{|c|c|c|c|c|c|c|c|c|c|c|c|}
\hline & & - & - & - & - & 5 & 16 & - & - & - & - \\
\hline \multirow{15}{*}{$\begin{array}{l}\text { Om4 } \\
\text { Dorylaimidae }\end{array}$} & Mesodory- & - & - & 13 & - & - & - & 5 & 8 & - & - \\
\hline & laimus & & & & & & & & & & \\
\hline & & 17 & 273 & 151 & 48 & 21 & 52 & - & - & - & 40 \\
\hline & Dorylaimus & - & - & - & 27 & 6 & - & - & 26 & - & - \\
\hline & & - & - & - & - & 8 & 8 & - & 120 & - & - \\
\hline & Eudorylaimus & - & - & - & - & 16 & - & - & - & - & - \\
\hline & & - & - & - & - & - & - & - & - & - & - \\
\hline & Dorylaimellus & - & - & - & - & - & 36 & - & 3 & - & - \\
\hline & & - & - & - & - & - & - & - & - & - & - \\
\hline & Laimydorus & - & - & - & - & - & - & 158 & 10 & 9 & 47 \\
\hline & & - & - & - & - & - & - & 146 & - & 26 & 85 \\
\hline & $\begin{array}{l}\text { Pachydory- } \\
\text { laimus }\end{array}$ & - & - & - & - & - & - & 15 & - & - & - \\
\hline & & - & - & - & - & - & - & - & - & - & - \\
\hline & Timmus & - & - & - & - & - & - & - & - & 5 & 6 \\
\hline & & - & - & - & - & - & - & - & - & - & - \\
\hline \multirow{2}{*}{$\begin{array}{l}\text { Om4 } \\
\text { Qudsiane- } \\
\text { matidae }\end{array}$} & Labronema & - & - & - & - & 26 & - & 37 & - & - & - \\
\hline & & - & - & - & - & - & - & - & - & - & - \\
\hline $\mathrm{Om} 5$ & Thornenema & - & - & - & - & - & - & - & - & - & - \\
\hline $\begin{array}{l}\text { Thornene- } \\
\text { matidae }\end{array}$ & & - & - & - & - & 2 & - & 20 & - & - & - \\
\hline
\end{tabular}

First row values are for the forest control and second row for the potato plots; $\mathrm{Ca}=\mathrm{Carnivorous}$ or predatory nematodes; $\mathrm{Om}=$ omnivorous nematodes; Values are per $100 \mathrm{~mL}$ soil sample. 
Table 3. Herbivorous soil nematodes associated with potato and control plots

\begin{tabular}{|c|c|c|c|c|c|c|c|c|c|c|c|}
\hline $\begin{array}{l}\text { Cp class/ } \\
\text { Family }\end{array}$ & Genus/species & Dec & Jan & Feb & Mar & Apr & May & Jun & Jul & Aug & Sep \\
\hline & Tylenchus- costatus & 75 & 58 & 15 & 163 & 8 & 23 & 37 & 21 & 13 & 42 \\
\hline \multirow[t]{2}{*}{ Tylenchidae } & T. filliformis & & & & & & & & & & \\
\hline & & 29 & 45 & 10 & 33 & 21 & 95 & 117 & 13 & 22 & 39 \\
\hline \multirow{4}{*}{$\begin{array}{l}\mathrm{Pl}_{2} \\
\text { Paratylen- } \\
\text { chidae }\end{array}$} & Paratylenchus & 132 & - & - & - & - & - & - & - & - & - \\
\hline & & - & - & - & 33 & - & - & - & - & 3 & - \\
\hline & Gracilacus & - & 23 & 25 & 14 & 49 & 14 & 25 & 24 & 39 & - \\
\hline & & - & - & - & - & - & - & - & - & - & - \\
\hline \multirow{2}{*}{$\begin{array}{l}\mathrm{Pl}_{2} \\
\text { Psilenchidae }\end{array}$} & Psilenchus hilarulus & - & 8 & 3 & 40 & - & - & 5 & - & - & - \\
\hline & & 2 & 21 & 28 & - & 3 & 97 & 24 & - & 17 & - \\
\hline \multirow{9}{*}{$\begin{array}{l}\mathrm{Pl}_{3} \\
\text { Hoplolaimidae }\end{array}$} & Hoplolaimus & - & 15 & - & - & - & - & - & - & - & - \\
\hline & galeatus & & & & & & & & & & \\
\hline & & - & - & - & - & 4 & - & - & - & - & - \\
\hline & $\begin{array}{l}\text { Helicotylenchus } \\
\text { mucronatus }\end{array}$ & - & - & - & - & - & - & 10 & 5 & - & - \\
\hline & & 9 & 107 & 10 & 16 & 7 & 7 & 15 & 39 & 9 & 170 \\
\hline & $\begin{array}{l}\text { Rotylenchus } \\
\text { buxophilus }\end{array}$ & - & - & - & - & - & - & - & - & - & - \\
\hline & & - & - & 48 & 48 & 9 & 22 & 221 & 15 & 25 & 43 \\
\hline & Scutellonema & - & - & - & - & - & - & - & - & - & - \\
\hline & & - & - & - & - & - & - & - & 14 & - & - \\
\hline \multirow{3}{*}{$\begin{array}{l}\mathrm{Pl}_{3} \\
\text { Meloidogy- } \\
\text { nidae }\end{array}$} & Meloidogyne & 21 & 51 & 10 & - & - & 5 & 11 & 22 & 13 & 21 \\
\hline & microcephala & & & & & & & & & & \\
\hline & & - & 14 & 80 & - & - & - & 65 & 22 & 17 & - \\
\hline \multirow{2}{*}{$\begin{array}{l}\mathrm{Pl}_{3} \\
\text { Pratylen- } \\
\text { chidae }\end{array}$} & Pratylenchus & - & 15 & - & - & 3 & - & - & - & - & - \\
\hline & & - & - & - & - & 4 & 31 & - & - & - & - \\
\hline \multirow{3}{*}{$\begin{array}{l}\mathrm{Pl}_{3} \\
\text { Heteroderidae }\end{array}$} & Heterodera & - & - & - & - & 9 & - & - & - & - & - \\
\hline & & & & & & & & & & & \\
\hline & & - & - & - & - & - & - & - & - & - & - \\
\hline \multirow[t]{2}{*}{$\begin{array}{l}\mathrm{Pl}_{3} \\
\text { Tylenchulidae }\end{array}$} & $\begin{array}{l}\text { Tylenchoryhn- } \\
\text { chus } \\
\text { annulatus }\end{array}$ & - & - & - & - & - & - & - & - & - & - \\
\hline & & - & - & - & - & - & - & 6 & - & - & - \\
\hline \multirow{4}{*}{$\begin{array}{l}\mathrm{Pl}_{5} \\
\text { Longidoridae }\end{array}$} & Xiphinema & 78 & 58 & 70 & 77 & 54 & - & 47 & 26 & 22 & 37 \\
\hline & & 28 & 49 & 28 & 16 & 27 & 7 & 6 & - & - & - \\
\hline & Longidorus & 9 & - & - & - & 44 & 50 & - & - & - & - \\
\hline & & - & - & - & - & - & 16 & - & - & - & - \\
\hline
\end{tabular}

First row values are for the forest control and second row values are for the potato plots; $\mathrm{Pl}=$ plant feeding nematodes or herbivorous nematodes; Values are per $100 \mathrm{~mL}$ soil sample. 


\subsubsection{Omnivorous Nematodes}

Omnivorous nematodes of the cp4 $\left(\mathrm{Om}_{4}\right)$ and $\mathrm{cp} 5\left(\mathrm{Om}_{5}\right)$, were recovered (Table 2). A combined total of three (3) families and nine (9) genera were recorded. There was no significant difference between the populations of the Om4 nematodes in both treatments, though the potato plots recorded a $119.65 \%$ increase in these nematodes as compared to the forest control. The Thornenematidae $\left(\mathrm{Om}_{5}\right)$ nematodes were only recorded for the potato plots.

\subsubsection{Plant-parasitic or Herbivorous Nematodes}

A total of nine (9) families and 14 genera of parasitic nematodes were extracted (Table 3). The cp2 $\left(\mathrm{Pl}_{2}\right), \mathrm{cp} 3\left(\mathrm{Pl}_{3}\right)$, and $\mathrm{cp} 5\left(\mathrm{Pl}_{5}\right)$, colonizer persister groups of plant nematodes were recovered. There was a $22.55 \%$ decrease in $\mathrm{Pl}_{2}$ nematodes in potato plots (mean 66.30) as compared to the control (mean 85.60). This difference was not significant $(\mathrm{P}<0.05)$. For the $\mathrm{Pl}_{3}$ nematodes, potato plots averaged 107.7 nematodes per $100 \mathrm{~mL}$ sample as compared to the 21.1 nematodes for the forest control. This difference was statistically significant at $\mathrm{P}>0.01$ and represented a $410.43 \%$ increase in these nematodes in potato plots. For the $\mathrm{Pl}_{5}$ nematodes, the forest control recorded higher populations (mean $=57.2)$ than the potato plots $(m e a n=17.7)$. This difference was statistically significant at $\mathrm{P}>0.001$. It represents a $30.94 \%$ decrease of $\mathrm{Pl}_{5}$ nematodes in potato plots.

\subsection{Potato Plots}

\subsubsection{Monthly Variations}

An analysis of the $\mathrm{Pl}_{3}$ nematodes of the potato plots did not reveal any significant difference between their populations. It is however noted that Helicotylenchus, Rotylenchus and Meloidogyne, each recorded nematodes in the range 7-170, 0-221, and 0-80 per $100 \mathrm{~mL}$ sample, during the entire sampling period. The analysis for monthly variation for the $\mathrm{Pl}_{3}$ nematodes also did not yield any statistically significant difference $(\mathrm{P}<0.05)$. However, most $\mathrm{Pl}_{3}$ nematodes were recovered in the months of June, September, February, and January i.e 321, 219, 138, and 121 $\mathrm{Pl}_{3}$ nematodes per $100 \mathrm{~mL}$ sample, respectively.

\subsection{Biomass Values}

\subsubsection{Nematodes Associated with Soil fertility}

The colonizer persister (cp) groups of nematodes recovered that contribute to soil fertility were the $\mathrm{Ba}_{1}, \mathrm{Ba}_{2}, \mathrm{Ba}_{3}$, and $\mathrm{Fu}_{2}$ (table 1, second row values). Among the bacterivorous nematodes a total of 4,171 bu was contributed to the ecosystem. Over $56 \%$ of the bacterivore total biomass was contributed by the $\mathrm{Ba}_{2}$ nematodes (Plectidae and Cephalobidae), followed by the $\mathrm{Ba}_{3}$, and then the $\mathrm{Ba}_{1}$. The fungal feeders $\left(\mathrm{Fu}_{2}\right)$ totaled 914 bu and of this, the Aphelenchoididae contributed $78 \%$ of the total. The total biomass for the nematodes that contribute to soil fertility was $5,085 \mathrm{bu}(\mathrm{Ba} / 4171+914 / \mathrm{Fu})$ and of this amount, the bacterivores contributed over $82 \%$ of the total.

\subsubsection{Suppression of Pest Species}

The colonizer persister (cp) groups of nematodes associated with pest control recovered in the potato plots were the carnivorous or predatory members $\mathrm{Ca}_{3}, \mathrm{Ca}_{4}$ and $\mathrm{Ca}_{5}$; and the omnivorous nematodes $\mathrm{Om}_{4}$ and $\mathrm{Om}_{5}$ (Table 2, lower row of values). The total predator biomass produced was $575 \mathrm{bu}$, with the $\mathrm{Ca}_{4}$ nematodes (Mononchidae) contributing $57 \%$ of the total, followed by the $\mathrm{Ca}_{5}$ nematodes. The combined biomass contribution of the omnivorous nematodes was $4,090 \mathrm{bu}$, of this, the $\mathrm{Om}_{4}$ (Dorylaimidae) dominated with over $97 \%$ of the total. The combined biomass for the nematodes that suppress pest species was 4665 bu. Of this over $87 \%$ was contributed by the omnivorous nematodes.

\subsubsection{Plant Feeding Nematodes}

The total biomass for the herbivorous nematodes was 5,420 bu (Table 3, lower row values). Of this over $59 \%$ was contributed by the $\mathrm{Pl}_{3}$ nematodes, followed by the $\mathrm{Pl}_{2}$ nematodes with over $24 \%$. Among the $\mathrm{Pl}_{3}$ nematodes, the Hoplolaimidae dominated, contributing over $77.81 \%$ of their total biomass.

Table 4 summaries information pertaining to all the nematodes recovered from potato plots and their biomass contribution to the ecosystem according to their ecological functional guilds. The values show that plant-parasitic nematodes $(\mathrm{Pl})$ dominated the ecology sampled (contributing $35.73 \%$ of the total biomass), followed by the nematodes associated with increasing soil fertility $(\mathrm{Ba}+\mathrm{Fu}, 33.53 \%)$, and then the pest control functional guilds (Ca and Om, 30.76\%) 
Table 4. Summary information on the soil nematodes recovered from samples obtained from potato plots

\begin{tabular}{llllll}
\hline Functional Guild & Families & Cp Classes & Genus & Contributed Biomass & \% Total Biomass \\
\hline Bacterivorous nematodes-Ba & 6 & $1,2,3$ & 9 & 4,171 & 27.50 \\
Fungivorous nematodes-Fu & 2 & 2 & 2 & 914 & 6.03 \\
Carnivorous nematodes-Ca & 6 & $3,4,5$ & 8 & 575 & 3.80 \\
Omnivorous nematodes-Om & 2 & 4,5 & 4 & 4,090 & 26.96 \\
Plant-parasitic nematodes-P1 & 12 & $2,3,5$ & 12 & 5,420 & 35.73 \\
\hline Total & 28 & $1-5$ & 35 & 15,170 & \\
\hline
\end{tabular}

\section{Discussion}

\subsection{Bacterivorous and Fungivorous Nematodes}

In comparing populations of these nematodes between the forest controls and potato plots, data from this investigation reveals that, potato plots recorded statistically significant or numerically higher numbers of these nematodes than the control. This is consistent with previous studies that have reported that, tillage environments stimulated the increase of these nematodes as compared to intact soils (Ferris \& Matute, 2003; Wardle, 1995; Lenz \& Eisenbeis, 2000). A direct relationship has been established in field plots between cumulative amounts of N mineralization and the nematode Enrichment Index (EI) which is based on the abundance of opportunistic bacterivorous and fungivorous nematodes (Ferris \& Matute, 2003). Enrichment nematodes and other soil organisms that feed on fungi and bacteria accelerate the decomposition of soil organic matter and increase mineralization, thereby releasing nutrients for plant growth (Chen \& Ferris, 1999; Akhtar \& Malik, 2000; Neher, 2001). In our crop rotation investigation (Matute \& Anders, 2012) we reported that intact soils had higher nematode populations (except for the omnivores) than conventional tilled soils. The explanation was that more organic residue was found in the no-till soils than the tilled soils. It will thus seem that the proliferation of the enrichment nematodes is more directly related to the amount of organic matter in the microenvironment, tillage being secondary. Therefore the reason why higher populations of enrichment nematodes were recorded in potato plots than the control is due to higher amounts of organic matter in the potato plots as compared to the forest controls.

The development of the colonizer-persister (cp) scale (T. Bongers \& M. Bongers, 1998; Bongers \& Ferris, 1999; Ferris et al., 2001), takes into account, the sensitivity to environmental perturbation. For example a cp 5 nematode is more sensitive to changes in the environment than a cp2 nematode. It is because of this attribute of nematodes that makes then excellent bioindicators of environmental conditions (Matute et al., 2009). In this study, the only statistically significant difference $(\mathrm{P}<.05)$ in the populations of the enrichment nematodes was with the $\mathrm{Ba}_{3}$ group of nematodes i.e the Prismatolaimidae. Potato plots recorded higher populations of these nematodes by over $467 \%$ (means: forest 6.1 vs 34.6 potato) as compared to the forest controls. The Prismatolaimidae seem to have responded more positively to the tilled potato plot environment with higher amounts of organic matter, as compared to the undisturbed forest environment with presumably lower organic matter content. Thus in the absence of active pollutants, it would seem that the organic matter content of an environ is a more important factor in determining the cp classes of enrichment nematodes present as compared to a physical perturbation.

\subsection{Carnivorous and Omnivorous Nematodes}

There are two functional guilds of nematodes that are associated with pest species control in the soil, the carnivores or predators and the omnivores. These nematodes also signify an unpolluted environment, an undisturbed environment, etc. Data from this study reveal that the undisturbed forest environment recorded higher populations of the predatory nematodes as compared to tilled potato plots, though this difference was not statistically significant. These results therefore corroborate results of a previous investigation on crop rotations (Matute \& Anders, 2012). However, with the omnivorous nematodes, higher populations were recorded in the potato plots $\left(\mathrm{Om}_{4}\right)$, while the Thornenematidae $\left(\mathrm{Om}_{5}\right)$, were absent in the forest controls. While it seems obvious that carnivorous nematodes were more sensitive to perturbation than the omnivores, another probable explanation for this difference in abundance is attributed to food sources. The omnivores obtained their food from both the crop root sources and via carnivory, while the carnivores depended only on predation in competition with the omnivores. Therefore, while perturbation has an effect on the presence and abundance of large bodied nematodes of the cp3-5 classes, the presence of suitable and abundant food sources is also thought to be a factor. As a consequence, 
omnivores are thought to have played a greater role in pest species control in this study as compared to the carnivores because of their abundance and total biomass contribution.

\subsection{Plant-parasitic Nematodes}

Plant-parasitic nematodes exhibit host specificity as a consequence, the primary driver of their populations in the soil is dependent on the plant host species. The decrease in the populations of the $\mathrm{Pl}_{2}$ and $\mathrm{Pl}_{5}$ nematodes in potato plots as compared to the forest control is therefore attributed to host specificity. Likewise the population of $\mathrm{Pl}_{3}$ nematodes was statistically significantly higher in the potato plots as compared to the forest controls. It would

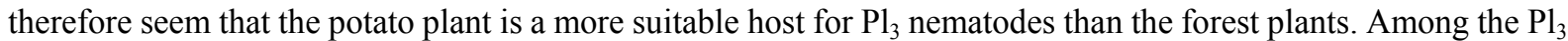
nematodes, the Hoplolaimidae have the most potential of being destructive to the potato crops.

\subsection{Relative Biomass Contribution}

Table 4 summarizes the relative biomass contribution by each nematode guild in the potato plots. The combined contribution of the enrichment nematodes $(\mathrm{Ba}+\mathrm{Fu})$ was $33.53 \%$ and that of the plant-feeding nematodes $35.73 \%$. That the parasitic nematodes were more abundant than the nematodes that contribute to soil fertility, suggest that the destructive capability of the parasitic nematodes outweighs the contribution to soil fertility, making plant-parasitic nematodes a potential threat to potato production in the study area. The combined biomass contribution for the pest species control nematodes $(\mathrm{Ca}+\mathrm{Om})$ was $30.76 \%$, a value lower than that of the plant-parasites. Considering that the omnivores and carnivores feed on the enrichment nematodes and plant feeders $(33.53+35.73 \%)$, it seems overwhelming for the pest control species to have been able to suppress the parasitic nematodes, to a level that would have minimized their destructive ability.

\section{Conclusion}

In this investigation a total of 26 nematode families and 45 nematode genera were recovered. According to their principal ecological function, these nematodes were categorized as follows; soil enrichment or soil fertility (bacterivores and fungivores; 8 families, 12 genera), pest species suppression or control nematodes (carnivores and omnivores; 9 families, 19 genera), and the plant-feeding species (herbivores; 9 families, 14 genera). It was found that depending on the trophic group, the difference in population abundance between the cropped plots and the forest control seems to have been linked to physical perturbation, soil organic matter content, or food sources.

Data from this study also reveals that Solanum tuberosum is a suitable host for plant-parasitic nematodes of the colonizer-persister (cp) group $\mathrm{Pl}_{3}$ particularly Helicotylenchus mucronatus, Rotylenchus buxophilus and Meloidogyne microcephala. These nematodes therefore are considered a potential threat to the production of this crop in the study area. In addition soil conditions that would increase the populations of the enrichment nematodes (e.g increase organic matter) and the predatory nematodes (especially the omnivores) may offset the destructive potential of the parasitic nematodes.

Alteration of the structure or function of the soil food web may be a consequence of environmental perturbation. It may also be an explicit management objective of environmental conservation and restoration programs, or of agricultural production practices (Ferris et al., 2001). This study also suggests that the amount of organic matter and food sources in the soil also has a direct bearing on the nematode community structure or soil food web structure.

\section{Acknowledgement}

We are grateful to the NASA/Arkansas Space Grant Consortium/EPSCoR for part funding of this research.

\section{References}

Akhtar, M., \& Malik, A. (2000). Roles of organic soil amendments and soil organisms in the biological control of plant-parasitic nematodes (a review). Biores. Technol., 74, 35-47.

Barker, K. R. (1985). Nematode extraction and bioassays pp 19-35 In K. R. Barker, C. C. Carter, \& S. N. Sasser (Eds), An advanced treatise on Meloidogyne, Vol. 2. North Carolina State University Graphics, Raleigh, North Carolina.

Bongers, T., \& Bongers, M. (1998). Functional diversity of nematodes. Applied Soil Ecology, 10, $239-251$.

Bongers, T., \& Ferris, H. (1999). Nematode community structure as a bioindicator in environmental monitoring. Trends Ecol. Evol., 14(6), 224-228.

Chen, J., \& Ferris, H. (1999). The effects of nematode grazing on nitrogen mineralization during fungal decomposition of organic matter. Soil Biol. Biochem., 31, 1265-1279. 
Ferris, H., Bongers, T., \& de Goede, R. G. M. (2001). A framework for soil food web diagnostics: extension of the nematode faunal analysis concept. Applied Soil Ecology, 18, 13-29.

Ferris, H., \& Matute, M. M. (2003). Structural and functional succession in the nematode fauna of the soil food web. Applied Soil Ecology, 23, 93-110. http://dx.doi.org/10.1016/S0929-1393 (03)00044-1

Ferguson, J. G. (1920). Outline of Arkansas Geology. Arkansas State Bureau of Mines, Manufactures and Agriculture.

Hafez, S. L., Golden, A. M., Rashid, F., \& Handoo, Z. (1992). Plant-parasitic nematodes associated with crops in Idaho and Eastern Oregon. Nematropica, 22(2), 193-204.

Lenz, R., \& Eisenbeis, G. (2000). Short-term effects of different tillage in a sustainable farming system on nematode community structure. Biology and Fertility of Soils, 31, 237-244.

Matute, M. M., Perschbacher, P. W., \& Newell, A. (2009). Determination of benthic soil conditions using nematodes: Nematode food web conditions of fish ponds in the Lincoln and Desha Counties of Arkansas. Journal of the Arkansas Academy of Science, 63, 131-138.

Matute, M. M., \& Anders, M. (2012). Influence of rice rotation systems on soil nematode trophic groups in Arkansas. Journal of Agricultural Science, 4(2), 11-20.

Neher, D. (2001). Role of nematodes in soil health and their use as indicators. Journal of Nematology, 33, 161-168.

Sasser, J. N. (1989). Plant-parasitic nematodes: The farmer's hidden enemy. North Carolina State University Graphics, Raleigh, North Carolina.

Sokal, R. R., \& Rohlf, F. J. (1973). Introduction to Biostatistics (pp. 161-179). San Francisco: W. H. Freeman and Company.

Townsend, J. (2002). Practical statistics for environmental and biological scientists (pp. 91-105). John Wiley and Sons, Ltd.

Wardle, D. A. (1995). Impacts of disturbance on detritus food webs in agro-ecosystems of contrasting tillage and weed management practices. In M. Begon \& A. H. Fitter (Eds), Advances in Ecological Research (pp. 105-185), Vol. 26. New York, NY, USA: Academic Press.

Yeates, G. W. (2003). Nematodes as soil indicators: functional and biodiversity aspects. Biol. Fert Soils, 37, 199-210. http://dx.doi.org/10.1007/s00374-003-0586-5 